\title{
Jaewon Ahn*
}

Jungsam Yum**

\section{An Attempt to Read Mencius' Philosophy with Help of Cicero: Focusing on the Relationship of the Term ren 仁 with the Building of Empire}

DOI: http://dx.doi.org/10.12775/LC.2019.048

\begin{abstract}
Already in $17^{\text {th }}$ century, $\mathrm{Ph}$. Couplet (1623-1693) used Ciceronian terminology to interprete the texts of Confucian philosophy, including that of Mencius (372-289 BCE), an important philosopher especially in terms of understanding Chinese ethics and morals. This paper attempts to read Mencius' political term "empire" in the context of political philosophy. The paper observes Mencius's political idea with help of that of Cicero. For this, it demostrates how and why Mencius introduces the ren as a principle of Kingship and the building of Empire. According to him, the ren is a core principle in operating the empire that was formulated with the tianxia ("all-underheaven"). However, the ren is an ambivalent concept. On one side, the ren is a universal value that stands fundamentally against violence. On the other side, historically to see, the ren was an imperial ideology, because as a part of the "all-under-heaven" policy represented by Mencius was de facto nothing but a regional hegemon.
\end{abstract}

Keywords: Mencius, Cicero, ren, humanitas, Chinese empire, true king, perfect man, orator perfectus

* Professor in Institute of Humanities, Seoul National University. His research focuses on comparative studies between East and West and reception history of classical philology in Asia.

E-mail: numeniu@snu.ac.kr | ORCID: no digital identifier.

** Research Professor in Inha Institute for Chinese Studies, Inha University. Her research focuses on history of Chinese logic and Chinese characters.

E-mail: yum.jungsam@gmail.com | ORCID: no digital identifier. 


\title{
Próba odczytania filozofii Mencjusza przy pomocy Cycerona: \\ O relacji terminu ren 仁 $\mathrm{z}$ budowaniem imperium
}

\begin{abstract}
Streszczenie: Już w XVII wieku Ph. Couplet (1623-1693) wykorzystywal Cyceronową terminologię do interpretacji konfucjańskiej, w tym Mencjusza (372-289 p.n.e.) filozofa istotnego przede wszystkim dla rozumienia chińskiej etyki i moralności). Celem artykułu jest próba odczytania terminu Mencjusza "imperium” w kontekście filozofii politycznej. Artykuł bada polityczną ideę Mencjusza przy pomocy idei Cycerona. W tym celu ukazuje, jak i dlaczego Mencjusz wprowadza ren jako podstawę Królestwa i budowania Imperium. Według niego ren jest podstawową zasadą funkcjonowania imperium opartego na tianxia („,wszystko, co pod niebem”). Jednakże, jest to termin niejednoznaczny. Z jednej strony jest to wartość uniwersalna, która zdecydowanie sprzeciwia się przemocy. Z jednej strony ren jest wartością uniwersalną, z drugiej jednak, z perspektywy historycznej, staje się elementem ideologii imperialnej, ponieważ jako część zasady „wszystko, co pod niebem” w ujęciu Mencjusza oznacza de facto regionalnego hegemona.
\end{abstract}

Słowa kluczowe: Mencjusz, Cyceron, ren, humanitas, cesarstwo chińskie, prawdziwy król, człowiek doskonaty, orator perfectus

Mencius 孟子 (372-289 BC) is an important philosopher especially in terms of understanding Chinese ethics and morals, because Mencius is usually read in the perspective of moral philosophy and religion. A good evidence for this is Mencius and Aquinas: Theories of Virtue and Conceptions of Courage (Yearley 1990). This book is a comparative study between Mencius and Aquinas, as shown in the title. However, Mencius is an important philosopher especially in terms of understanding Chinese empire, because his understanding on ren is to be considered as a fundamental principle for building an empire. To be sure, there are numerous papers on Mencius' political philosophy (Liang [\&] Sullivan 2010: 212-236; Kim 2011:371-399). However, it is not easy to find papers to read Mencius in terms of "empire". For this, we draw attention to ways the term ren 仁 used for justifying empire by Mencius. This paper attempts to read Mencius's political philosophy with help of Cicero.

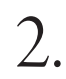

The ren is the pivotal term for understanding the moral philosophy of Mencius. The political philosphy of Mencius also was originated in this concept. Confirming this, we begin with replying to the question of how Mencius defines it. According to Mencius, everyone has the ren, which means a commiserating mind in nature. 
所以謂人皆有不忍人之心者、今人乍見孺子將入於井、皆有忧惕惻隱之心、 所以內交於孺子之父母也、非所以要譽於鄉黨朋友也、非惡其聲而然也。

由是觀之、無惻隱之心、非人也、無羞惡之心、非人也、無辭讓之心、

非人也、無是非之心、非人也。（Kim 2013: 公孫丑上6)

Here is why I say that all human beings have a mind that commiserates with others. Now, if anyone were suddenly to see a child about to fall into a well, his mind would be filled with alarm, distress, pity, and compassion. That he would react accordingly is not because he would hope to use the opportunity to ingratiate himself with the child's parents, nor because he would seek commendation from neighbors and friends, nor because he would hate the adverse reputation [that could come from not reacting accordingly]. From this it may be seen that one who lacks a mind that feels pity and compassion would not be human; one who lacks a mind that feels shame and aversion would not be human; one who lacks a mind that feels modesty and compliance would not be human; and one who lacks a mind that knows right and wrong would not be human. (Bloom 2011:2A6)

It is remarkable that Mencius begins his argument with the case of the chind in danger. Mencius deals the issue of human nature in the universal perspective. According to him, human nature consists of four sprouts (=virtues), as follows.

惻隱之心、仁之端也。羞惡之心、義之端也。辭讓之心、禮之端也。 是非之心、智之端也。（Kim 2013: 公孫丑上6)

The mind's feeling of pity and compassion is the sprout of humaneness [ren 仁]; the mind's feeling of shame and aversion is the sprout of rightness [ $y i$ 義]; the mind's feeling of modesty and compliance is the sprout of propriety $[l i$ 禮 $]$; and the mind's sense of right and wrong is the sprout of wisdom [zhi 智]. (Bloom 2011:2A6)

These four sprouts of Mencius are to be compared with cardinal virtues of Cicero. In this regard, Ph. Couplet (1623-1693), who edited the manuscript of Intorcetta (16261696) and published it in the title of Confucius Sinarum Philosophus at Paris in 1687, translated the four sprouts with the terms of Cicero.

Haec autem per quatuor veluti virtutes Cardinales videlicet Gin, Li, Y, Chi, id est, pietatem conenientiam, justitiam, prudentiam, philosophus studet explanare. (The philosopher [sc. Confucius] likes to explain these principles (sc. 元亨利貞) with the four virtues of $\mathrm{Gin} \mathrm{Li}, \mathrm{Y}$, and $\mathrm{Chi}$, just as the cardinal virtues of piety, convenience, justice and prudence).

(Couplet 1687: Proemialis Declaratio p. xlvii)

The cited in the above makes clear that Couplet read the texts of Confucian philosophy, including that of Mencius in the eye of Cicero. Here is a remark of Cicero on virtue (De Inv. II 53, 159):

Virtue may be defined as a habit of mind (animi) in harmony with reason and the order of nature. It has four parts: wisdom justice, courage, temperance.

(Hubbell [tr.] 1968: 327) 
The four sprouts of Mencius seem to be closer to sub-categories of Cicero's humanitas idea. According to Helmut Storch (2006), "in humanitas as 'humanity' the following features emerge: 1. philanthropic respect, especially compassion (misericordia), 2. intelligent and tactful affability (urbanitas), 3. feeling for natural human solidarity (sensus humanitatis), 4. cultured humanity (eruditio, doctrina), 5. civilization (cultus). As early as Cicero's oration, Pro Sex. Roscio (84 BC) almost all shades of these can be found". On this account, it is natural that Julien Stanislas translated the four sprouts into Latin like this.

Libri II. \$. XVI. Misericordiae animum homines omnes habent: (40) odii animum homines omnes habent: observantiae et reverentiae animum homines omnes habent: (41) approbationis et vituperationis animum homines omnes habent. Misericordiae animus, humanitas est: pudoris et odii animus, aequitas est: observantiae et reverantiae animus, urbanitas est: approbationis et vituperationis animus prudentia est. Humanitas, aequitas, urbanitas, prudentia, non ab extrinseco conflatae sunt in nobis: nos ab initio habemus illas: solummodo non (42) cogitamus. (Stanislas 1824-29: 131)

Stanislas translated ren 仁 into humanitas, while Irene Bloom translated it into "humaneness". The ren is predicated with misericordiae animus, which is translated from the original text of “惻隱之心.” Mencius argues that animus misercordiae is a first virtue that a king should have.

孟子曰、人皆有不忍人之心。先王有不忍人之心、斯有不忍人之政矣。以不忍 人之心、行不忍人之政，治天下、可運之掌上。(Kim 2013: 公孫丑上6)

Mencius said, "All human beings have a mind that cannot bear to see the sufferings of others. The ancient kings had such a commiserating mind and, accordingly, a commiserating government. Having a commiserating mind, and effecting a commiserating government, governing the world was like turning something around on the palm of the hand. (Bloom 2011:2A6)

Mencius defines animus misercordia as the first principle of Kingship. Thus, this idea is not the same as the compassion among individual persons. The animus misercordiae of Mencius is to be compared to the animus misercordiae of Zeus in Odyssey ${ }^{1}$. The epic begins with the scene that the Olympian Gods except Poseidon saw Odysseus in the animus misercordiae in the first book of Odyssey. Interestingly, Cicero also used the misercordia in the sense of humanity.

Or. pro Sext. Rosc. 154. It belongs to wise men, furnished with the authority and power which you possess, to apply the most effective remedies to the evils from which the republic especially suffers. There is no one among you who does not know that the Roman people, who were formerly considered to be most lenient towards their enemies, are suffering today from cruelty towards its own citizens. Banish this cruelty from State, gentlemen. Do not allow it to stalk abroad any longer in this republic, for it not only involves this evil, that it has removed so many citizens by a most atrocious death, but it has also stifled all feeling of pity in the hearts of men

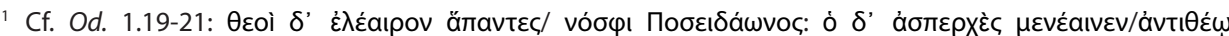

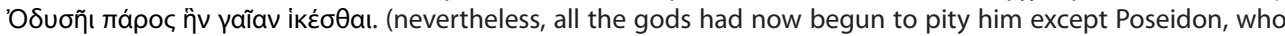
still persecuted him without ceasing and would not let him get home. Trans. by S. Butler, rev. by T. Power and G. Nagy). 
generally most merciful, by familiarizing them with all kinds of evils. For when, every hour, we see or hear of an act of cruelty, even those of us who are by nature most merciful lose from our hearts, in this constant presence of pains, all feeling of humanity. (Warmington 1967 [1930]: 261-263)

Cicero argued that a state without misercordia is not a republic. Mencius took a similar position to that of Cicero.

是以惟仁者、宜在高位。不仁而在高位、是播其惡於衆也。上無道揆也、 下無法守也。朝不信道、工不信度。君子犯義、小人犯刑。國之所存者幸也。 故曰、城郭不完、兵甲不多、非國之災也。田野不辟、貨財不聚、非國之害 也。上無禮、下無學、賊民興、喪無日矣。(Kim 2013: 離婁上1)

Therefore, only the humane should be in high positions. When one lacking in humaneness occupies a high position, his wickedness spreads to everyone. When, above, the Way is not considered, then, below, the laws are not preserved; when courtiers do not believe in the Way, artisans do not believe in measures; when gentlemen offend against rightness, small people offend against the criminal laws. It is a matter of sheer good fortune if the state survives. Therefore it is said, 'When the city walls are not complete or arms abundant, this is not a calamity for the state. When fields and wilds have not been opened up to cultivation or goods amassed, this is not a threat to the state. But when, above, there is an absence of ritual propriety and, below, an absence of learning, rebels will rise up and the state will soon perish.' (Bloom 2011:4A1)

Mencius also stresses the ren (animus misercordiae) over laws, because the lacking of humaneness is the first cause of all kinds of disorder. A clear difference between Mencius and Cicero is that Mencius gave emphasis on the true kingship, while Cicero underlined the good republic. Regarding this, the ren is not to be regarded as a sub idea to human nature, even though it is alloted to the misericordiae. Mencius considered it to be pater familias. One can find it in the following.

\section{孟子曰、仁之實、事親是也。義之實、從兄是也。（Kim 2013: 離婁上27）}

Mencius said, "The most authentic expression of humaneness is serving one's parents; the most authentic expression of rightness is following one's older brother. (Bloom 2011:4A27)

For Cicero, humanitas is a technical term that comprises the following components: natura humana, conditio mortalis, natura hominis, natura generis humani, mansuetudo, cultus, doctrina, dignitas, pietas, fides, honestas, iustitia, gravitas, virtus, integritas, lepos, facetiae, elegantia, eruditio, urbanitas, hilaritas, iocositas, festivitas, sapientia, moderatio, modestia, aequitas, omitas, benignitas, clementia, misericordia, benevolentia, facilitas, mollitudo, liberalitas, munificentia, and so on. For Mencius, however, animus misercordiae is not a component of humanitas, as argued in the above. The ren of Mencius is a key concept like Cicero's humanitas. It could be the reason why Stanislas translated the ren into humanitas. On top of this, we should pay attention that Cicero's humanitas is concerned with human education. Mencius regarded ren as teaching. 
昔者、子貢問於孔子曰、夫子聖矣乎。孔子曰、聖則吾不能。我學不厭而敉不 倦也。子貢曰、學不厭、智也。呚不倦、仁也。仁且智、夫子朁聖矣。

(Kim 2013: 公孫丑上2)

Formerly Zigong asked Confucius, 'Is the Master a sage?' Confucius said, 'A sage I cannot be. I am, in learning, indefatigable and, in teaching, untiring.' Zigong said, 'Your learning indefatigably — this is wisdom. Your teaching untiringly—this is humaneness. Being humane and being wise, the Master is indeed a sage.' (Bloom 2011: 2A2)

What does the "humaneness" mean? The humaneness of Mencius aims at perfection or completeness that is parallel to Cicero's idea of perfectio. Stanislas translated Chinese 君子 (perfect man) as vir perfectus. The difference between them is clear that the ideal man of Mencius is directed to a sage, while that of Cicero is an orator perfectus who is identified with an ideal statesman (cf. Ahn 2011: 1-22). But it is noticeable that Mencius also highlighted only the idea of ideal King. The original formulation for this is 修己治人 that is translated as "self-cultivation and governing people" (Ahn 2012: 461-520). The self-cultivation was stressed later by Neo-confucians. We believe that Mencius' dialog was about how to teach ideal King and how to build the true kingship. It is formulated with 王道政治 by Mencius. According to Mencius, all in all, the ren is a core concept of the true kingship. This is the foundation on which we consider the ren as political term.

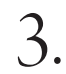

It is time to reply to the question why the ren is regarded as a basic principle for building the true kingship. According to Mencius, the ren is the principle according to which the all-under-world can be alive. He says that the world itself is full of the ren. He explaines it with the example of "Ox mountain":

孟子曰、牛山之木、嘗美矣。以其郊於大國也、斧斤伐之、可以爲美乎。是其 日夜之所息、雨雲之所潤、非無萌菜之生焉。牛羊又從而牧之、是以若彼濯濯 也、人見其濯濯也、以爲未嘗有材焉、此豈山之性也哉。雖存乎人者、豈無仁義 之心哉。其所以放其良心者、亦猶斧斤之於木也、旦旦而伐之、可以爲美乎。 其日夜之所息、平旦之氣、其好惡與人相近也者幾希、則其旦書之所爲、有梏 亡之矣。梏之反覆、則其夜氣不足以存、夜氣不足以存、則其違禽獸不遠矣。 人見其禽獸也、而以爲未嘗有才焉者、是豈人之情也哉。

(Kim 2013: 告子 上8)

Mencius said, "The trees on Ox Mountain were once beautiful. But being situated on the outskirts of a large state, the trees were cut down by axes. Could they remain beautiful? Given the air of the day and the night, and the moisture of the rain and the dew, they did not fail to put forth new buds and shoots, but then cattle and sheep came along to graze upon them. This accounts for the barren appearance of the mountain. Seeing this barrenness, people suppose that the mountain was never wooded. But how could this be the nature of the mountain? So it is also with what is preserved in a human being: could it be that anyone should lack the mind of humaneness and rightness? If one lets go of the innate good mind, this is like taking an ax to a tree; 
being cut down day after day, can [one's mind] remain beautiful? Given the rest that one gets in the day and the night, and the effect of the calm morning qi, one's likes and dislikes will still resemble those of other people, but barely so. And then one can become fettered and destroyed by what one does during the day; if this fettering occurs repeatedly, the effect of the night $q i$ will no longer be enough to allow one to preserve his mind, and he will be at scant remove from the animals. Seeing this, one might suppose that he never had the capacity for goodness. But can this be a human being's natural tendency? Thus, given nourishment, there is nothing that will not grow; lacking nourishment, there is nothing that will not be destroyed. Confucius said, 'Hold on and you preserve it; let it go and you lose it. The time of its going out and coming in is not fixed, and there is no one who knows the place where it goes.' In saying this, he was referring to the mind. (Bloom 2011: 6a8)

In this regard, Ivanhoe (2011: xvi) mentions that "heaven has a plan for human being, both individually and collectively". How does the heaven's plan then come true? According to Mencius, it is by the ren. He regards the ren as a kind of categorical imperative by which everything from ordinary person to king is regulated. Mencius makes it clear in the following.

孟子曰、三代之得天下也以仁、其失天下也以不仁、國之所以廢興存亡者亦然。 天子不仁、不保四海。諸侯不仁、不保社稷。卿大夫不仁、不保宗廟。士庶人不 仁、不保四體。今惡死亡而樂不仁、是猶惡醉而强酒。(Kim 2013: 離婁上3)

Mencius said, "The way the three dynasties gained the empire was through humaneness, and the way they lost it was through not being humane. So it is too in the flourishing or decline of states, and in their preservation or loss. If the Son of Heaven is not humane, he will be unable to protect all within the four seas. If a feudal lord is not humane, he will be unable to protect the altars of the soil and grain. If a high officer is not humane, he will be unable to protect the ancestral temple. And if an ordinary person is not humane, he will be unable to protect his four limbs. Now, to dislike death and ruin and yet to take pleasure in not being humane is like disliking drunkenness and yet forcing oneself to drink to excess." (Bloom 2011: 4A3)

Everybody is required to gain the ren. The question is how to gain it. This question is vital to the person who wants to be king. For him Mencius advises to have the virtue that mediates the king with the ren, which helps to unite the king and people. The virtue is a medium of the ren for true kingship:

行仁政而王、莫之能禦也。且王者之不作、未有疏於此時者也。民之憔悴於虐 政、未有甚於此時者也。飢者易爲食、渴者易爲飲。孔子曰、德之流行、速於 置郵而傳命。（Kim 2013: 公孫丑上 1)

If he will practice humane government, he will become a true king, and no one will be able to stand in his way. Moreover, there has never been a longer time since a true king appeared, never a time when the people's sufferings from tyrannical government have been so great. It is easy to provide food for the hungry, easy to provide drink for the thirsty. Confucius said, 'The transmission of Virtue is faster than the transmission of an order through the post.' (Bloom 2011:2A1)

Literally to see, the remark "humane" is translated from the term of the ren, which is an innate virtue by heaven. Thanks to the ren, the true king can make all-under-heaven 
in order. Because of this, it is necessary to have the virtue of the self-cultivation under the principle of the ren. He gave an instruction.

孟子曰、君子深造之以道、欲其自得之也。自得之則居之安、居之安則資之深、 資之深則取之左右逢其原、故君子欲其自得之也。（Kim 2013: 離婁下14）

Mencius said, "The noble person delves into it deeply according to the Way, wishing to get it in himself. As he gets it in himself, he abides in it calmly; abiding in it calmly, he trusts in it deeply; trusting in it deeply, he draws on its source, which he finds both to his left and to his right. This is why the noble person wishes to get it for himself." (Bloom 2011: 4B14)

The reason why the king should have the virtue of the self-cultivation of the king is explained from that people submits to the king not by force but by the self-persuasion when they belive that the king has the virtue of the ren.

以力服人者、非心服也、力不贍也。以德服人者、中心悅而誠服也。 (Kim 2013: 公孫丑上3)

When one uses force to make people submit, they do not submit in their hearts but only because their strength is insufficient. When one uses virtue to make people submit, they are pleased to the depths of their hearts, and they sincerely submit. (Bloom 2011:2A3)

As evidenced above, the true king should have the ren, because people does not submit voluntarily to the king who is inhumane. The ren is, thus, not only a virtue of self-cultivation but also a significant principle of ruling people and governing country. There is no reason for not considering the ren as a political concept. We invite Mencius again as a witness:

以力假仁者覇、覇必有大國。以德行仁者王、王不待大。(Kim 2013: 公孫丑上3)

One who, supported by force, pretends to being humane is a hegemon, and a hegemon has to have a large state. One who out of virtue practices humaneness is a true king, and a true king does not need anything large. (Bloom 2011:2A3)

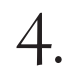

It is time to see the relationship between king and people and the relationship of empire with small kingdoms in terms of the ren. As for the relationship of king and people, Mencius contends that the heaven is represented by people.

孟子曰、民爲貴、社稷次之、君爲輕。是故得乎丘民而爲天子、得乎天子爲諸侯、 得乎諸侯爲大夫。諸侯危社稷則變置、犧牲兓成、染盛既潔、祭祀以時、然而旱乾 水溢、則變置社稷。（Kim 2013: 盡心下14） 
Mencius said, "The people are of greatest importance, the altars of the soil and grain are next, and the ruler is of least importance. This is why one who gains the allegiance of the tillers of the fields will become the Son of Heaven, and one who gains the allegiance of the Son of Heaven will become one of the several lords, and one who gains the allegiance of the several lords will become a great officer. When one of the lords endangers the altars of the soil and grain, he is replaced. When the sacrificial animals have been perfect, the sacrificial vessels of millet have been pure, and the sacrifices have been timely, yet droughts or floods occur, then the altars should be replaced." (Bloom 2011: 7B14)

Mencius argues that people is more important than king, because the son of heaven ( $t i \bar{a} n z \grave{l}$ 天子) is not a person who comes down from the heaven but the very person who gains the allegiance of people. This is the reason why Mencius insists on persuading the king to practice the ren. It is made clear in the following:

不仁而得國者有之矣、不仁而得天下未之有也。（Kim 2013: 盡心下13）

There have been cases where one who is not humane has gained control of a state but never a case where one who is not humane has gained control of all-under-Heaven. (Bloom 2011:7B13)

As seen in the above, Mencius puts great emphasis on the significance of the people in the country. He even contends that it is to be justified that the people and the subjects can overthrow or kill the king who does not follow the requirement of the people and rules them harshly. A king who does not respect the people is no more a true ruler. About the overthrow of the malicious King Zou 紂 of Shang dynasty Mencius remarks that "I have merely heard of killing a villain Zou, I have not heard of mudering the ruler." (Bloom 1B:8). This remarking was hardly acceptable to Confucianists, because they generally regard kings and rulers highly. However, Mencius is convinced of that the king should be subordinate to the people, although he has presumably higher status than common people. Ivanhoe, points out that

Mencius was one of the first thinkers in the history of the world to insist that rulers and states exist to serve their people. The proper aim of a good state is the welfare of its people, and this is conceived in terms of the order, security, wealth, happiness, and education the people enjoy. Mencius believed the people are the only tangible indicator of good governance, and elite members of society must look to the people as the most reliable gauge of the quality of their rule and heed what this guide reveals. Much to the chagrin of the rulers in his own time and a number of later Chinese emperors as well, Mencius further argued that rulers who fail to serve their people lose the mandate to rule and can even be forcibly removed by those more qualified to fulfill Heaven's plan for its people. These forceful and at times quite subtle views about the role the welfare of the people plays in justifying political rule did not include any clear correlates to Western ideas about a right to revolt or to elect those who govern. Nevertheless, Mencius's views about the wisdom and importance of the people have the potential to significantly enrich present-day political philosophy. (Ivanhoe 2011: xvi)

To Ivanhoe's view, we add that the ren is the prerequisite condition for gaining the empire, because the empire of all-under-heaven is accessible only to the one who is humane (ren 仁). Henceforth, the ren is the principal principle to build an empire. The reason 
why Mencius emphasizes the significance of the ren is explained from the fact that he lived during the latter part of the Zhou dynasty (traditional dates: 1122-249 BC), so-called the Warring States period (403-221 BC). In order to bring an end to the wars and to bring peace into the world, he wrote Mencius, which is the very text of reflection on the questions of how to end the wars between small kingdoms and of how to peacefully build the imperium of all-under-heaven. In this text, he explains how the ren brings harmony among kingdoms and how the ren can make a peaceful relationship between empire and subjective kingdoms. Concerning this, two things deserve emphasis. On one hand, Mencius contends that a large kingdom should serve a small state according to the principle of ren. Here is his remark:

齊宣王問曰、交隣國有道乎。孟子對曰、有惟仁者、爲能以大事小。是故湯事 葛、文王事昆夷。惟智者、爲能以小事大。故大王事獯寚、句踐事吳。 以大事小者、樂天者也。以小事大者、畏天者也。樂天者保天下、畏天者保其 國。(Kim 2013: 梁惠王下3)

King Xuan of Qi asked, "Is there a way of conducting relations with neighboring states?" Mencius replied, "There is. But only one who is humane is able to serve a small state with a large one, as was the case when Tang served Ge and King Wen served the Kun tribes. Only the wise are able to serve a large state with a small one, as was the case when Tai Wang served the Xunyu and Goujian served Wu. One who with a large state serves a small one delights in Heaven, while one who with a small state serves a large one is in awe of Heaven. Through delighting in Heaven one preserves all-under-Heaven, and through being in awe of Heaven one preserves his state. (Bloom 2011:1B3)

As evidenced in the citation, it is clear that the ren is the principle that opens a way to the imperium of all-under-heaven. On the other hand, it is remarkable that Mencius declaims explicitly to avoid making war.

孟子曰、春秋無義戰、彼善於此則有之矣。征者、上伐下也。敵國、不相征也。 (Kim 2013: 盡心下2)

Mencius said, "In the Spring and Autumn Annals there are no just wars. It does happen that some are better than others. 'Punishment' involves superiors attacking inferiors. Opposing states do not 'punish' each other.' (Bloom 2011:7B2)

It is obvious that Mencius was against war in essence, because he contends that the world will be be peaceful, if the ren prevails among kingdoms. Mencius remarks:

有人曰、我善爲陳、我善爲戰、大罪也。國君好仁、天下無敵焉。 (Kim 2013:盡心下4)

There are people who say, 'I am good at deploying troops, I am good at waging war.' This is a grave crime. If the ruler of a state loves humaneness, he will have no enemy in the world. (Bloom 2011:7B4) 
It is not easy to answer to the question of whether Mencius was against bellum iustum, because the meaning of bellum iustum seems to be similar to those of the Chinese character zheng 征 but they are not identical to each other. All in all, according to our reading, Mencius takes position for bellum iustum. It is manifested in the following:

仁人無敵於天下、以至仁、伐至不仁、而何其血之流杵也。 (Kim 2013: 盡心下3)

A humane person has no enemy in the world. When the one who was most humane attacked the one most devoid of humaneness, how could it have been possible that 'the blood flowed so that it floated the pestles of the mortars'? (Bloom 2011: 7B3)

About the meaning of Chinese character zheng 征, it is noteworthy to see Ivanhoe's mention:

Mencius's views about just war continue to play a central and vital role in current Chinese conceptions of and responses to war. When the United States launched its second war with Iraq, there was widespread condemnation in the Chinese media, especially on the Internet. The most common criticism of the American action drew upon the distinction Mencius describes in passages such as $1 \mathrm{a} 5,1 \mathrm{~b} 11,7 \mathrm{~b} 2$, and $7 \mathrm{~b} 4$ between a campaign of justified punishment (zheng 征) and acts of interstate aggression. Many Chinese regarded the first Gulf War as a case of the former but saw the second war as a clear example of the latter. (Ivanhoe 2011: xvi)

In sum, the ren is a core principle in building an empire that was formulated with the all-under-heaven by Mencius. However, the ren is an ambivalent concept. On one side, the ren is a universal value that stands fundamentally against violence. On the other side, the ren is an imperial ideology because the all-under-heaven formulated by Mencius is considered as a superpower, historically seen. The question whether the modern China as a superpower still regards the ren as a principle of governance and diplomatic relationships is left unanswered in this paper. Nevertheless, it is obvious that the ideological principle of Chinese ancient empire system cannot be understood without a deep understanding of the ren. An evidence for this is the long-lasting relationships between China and Korea. The case of Korea may be exceptional because the history of Chinese is full of wars to that should have been opposed even by Mencius. However, it supports that the ren is to be regarded as a principle that was used for the building of Chinese empire.

\section{5.}

For better understanding of the ren as a fundamental principle for building an empire, lastly, we supplement some comparisons of the Mancius' ren with with some of Western ideas. Firstly, the ren can be compared to the idea of love in Christianity, as long as the former as a universal principle has some similar functions like the latter. The ren is, however, different from the love of Christianity in that it is not interested in explaining all-over-the heaven as does love. The ren is not a religious principle. Secondly, the true king of Mencius is to be 
considered as the philosophical king of Plato. But a fundamental difference between the two philosophers lies in that the true king has to prefer humaneness to justice. The third comparison is to be made between Mencius and Machiavelli. The true king described by Mencius is a person who stands exactly on the opposite point to the king of Machiavelli who approved violence as a political means. Fourthly, the true king is also different from orator perfectus of Cicero. The true king of Mencius does not need eloquence. Finally, the ren is based on the principle of size and magnitude. Mencius considers it natural that the small submits to the big. In this regard, the Mencius' ren seems to be similar to that of Thrasymachus, who claims that "justice is the advantage of the stronger" (Plato. Republic 1, 338c). The ren of Mencius differs, however, from the justice of Thrasymachus in that the ren is a principle that orders the stronger to give animus misercordiae to the weak. It is reinforced by Mencius' understanding of human nature in the following:

孟子曰、人之所以異於禽獸者幾希。庶民去之、君子存之。舜明於庶物、 察於人倫、由仁義行、非行仁義也。(Kim 2013: 離婁下19)

Mencius said "[ $\mathrm{t}]$ hat wherein human beings differ from the birds and beasts is but slight. The majority of people relinquish this, while the noble person retains it. Shun was clear about the multitude of things and observant of human relationships. Humaneness and rightness were the source of his actions; he did not just perform acts of humaneness and rightness. (Bloom 2011: 4B19)

Human being and beasts are almost same in nature, but there are some noble people who retain humaneness while beasts do not. It is the ren that makes the human as human. A deer should run away from a lion. This is the justice of Thrasymachus. According to Mencius, however, even a strong king should submit to people who are weak, according to the principle of $r e n$ that is a kind of categorical imperative from the heaven.

\section{Bibliography}

Ahn, Jaewon 2011. "A comparative study on Cicero's orator perfectus and Confucius' rex perfectus". Papers on Rhetoric 10: 1-22.

— 2012. “Some observations on Philippe Couplet (1623-1693)'s reading of Ye-King 『易經』_ focusing on his Latin translation of the Kien figure (謙掛)". Inmunnonchong [=The Journal of Humanities] 67: 461-510.

Cicero 1968 [1949]. De inventione. Transl. Harry M. Hubbell. Cambridge: Harvard University Press.

1967 [1930]. Oratio Pro Sexto Roscio Amerino. Warmington, Cambridge: Harvard University Press.

Confucius Sinarum philosophus, sive Scientia sinensis, latine exposita . Studio \& opera Prosperi Intorcetta, Christiani Herdtrich, Francisci Rougemont, Philippi Couplet patrum Societatis Jesu... Adjecta est tabula chronologica sinicé monarchić ab hujus exordio ad haec usque tempora 1687. Paris: D. Horthemels.

Ivanhoe, Philip J. (ed.) 2011. Mencius. Transl. Irene Bloom. New York: Columbia University Press. Kim Hak-Ju (ed.) 2013. Mencius 孟子. Seoul: Seoul National University Press. 
Kim, Sungmoon 2011. "Confucian Constitutionalism: Mencius and Xunzi on Virtue, Ritual and Royal Transmission". The Review of Politics 73: 471-399.

Lat, Cod. 6277.

Mutschler, Fritz-Heiner at al. 2009. Conceiving the Empire; China and Rome compared. Oxford: Oxford University Press.

Stanislas, Julien 1829. Meng Tseu vel Mencium inter Sinenses philosophos, ingenio, doctrina, nominisque claritate Confucio proximum, edidit, Latina interpretatione, ad interpretationem Tartaricam utramque recensita, instruixit, et perpetuo commentario, e Sinicis deprompto, illustravit Stanislaus Julien. Lutetiae Parisiorum: Societatis Asiaticae et Comitis de Lasteyrie impensis.

Storch, Helmut 2007. "Humanitas". Realencyclopädie der classischen Altertumswissenschaft. Leiden: Brill. http://referenceworks.brillonline.com/entries/brill-s-new-pauly/ humanitas-e.

Tao Liang [\&] Ian M. Sullivan 2010. "Political Thought in Early Confucianism”. Frontiers of Philosophy in China 5-2: 212-236.

Yearley, Lee H. 1990. Mencius and Aquinas: Theories of Virtue and Conceptions of Courage. New York: State University of New York Press. 